\title{
Evaluasi Peningkatan Practical Skills Siswa SMK Melalui Pelaksanaan Pelajaran Pekerjaan Dasar Teknik Mesin Berbasis Work-Based Learning
}

\author{
Sabbihisma Fattah Hardianto Putro ${ }^{* 1}$, Widiyanti ${ }^{2}$, Didik Nurhadi ${ }^{3}$ \\ ${ }^{1,2,3}$ Program Studi S1 Pendidikan Teknik Mesin Jurusan Teknik Mesin \\ ${ }^{1,2,3}$ Fakultas Teknik Universitas Negeri Malang \\ 1,2,3 Jalan Semarang No. 5, Malang 65145 \\ E-mail: irasudam01@gmail.com
}

\begin{abstract}
Abstrak: Work-Based Learning adalah pembelajaran berbasis kerja yang sedang dikembangkan diberbagai sekolah menengah kejuruan guna meningkatkan kemampuan practical skills yang dimiliki oleh peserta didik. Peningkatan kemampuan practical skills secara maksimal mampu mempermudah peserta didik bersaing memperoleh pekerjaan ketika lulus pembelajaran PDTM. Tujuan dari penelitian ini adalah untuk mengevaluasi hasil pembelajaran yang menggunakan metode work-based learning dengan metode CIPP. Penelitian ini menggunakan pendekatan deskriptif kuantitatif, dengan jenis instrumen angket dan dilakukan pada mata pelajaran PDTM di SMK Turen. Mata pelajaran tersebut ditempuh oleh kelas 10 TPM sebanyak 180 peserta didik dan dilakukan penelitian terhadap 60 peserta didik sebagai sampel uji coba dan 120 peserta didik sebagai sampel penelitian. Teknik analisis data menggunakan deskriptif dan dikelompokkan berbentuk persentase skala likert. Peningkatan practical skills dievaluasi menggunakan metode CIPP yaitu Context, Input, Process, dan Product. Hasil penelitian menunjukkan bahwa pembelajaran PDTM di SMK Turen yang menggunakan metode pembelajaran berbasis work-based learning dapat meningkatkan kemampuan practical skills peserta didik dengan baik meskipun masih terdapat beberapa indikator yang masih harus ditingkatkan. Harapannya adalah supaya dapat meningkatkan kemampuan practical skills peserta didik secara maksimal.
\end{abstract}

Kata kunci: work based learning, practical skills

\begin{abstract}
: work-based learning is work-based learning that is being developed in various vocational high schools to improve the practical skills that are owned by learners. Increasing practical skills can be maximally able to make it easier for learners to compete for work when passing the study of PDTM. The purpose of this research is to evaluate the learning outcomes using the work-based learning method with the CIPP method. This study uses a quantitative descriptive approach, with the type of poll instruments and performed on the PDTM subjects in SMK Turen. The subjects were reached by a tpm class of 10. 180 students and conducted research into 60 learners as sample trials and 120 learners as research samples. The data analysis techniques use descriptive and grouped the percentages of likert scales. Improved practical skills evaluated using cipp methods namely context, input, process, and product. The results showed that the study of pdtm in smk turen, which uses work-based learning method, can improve the practical skills of students well even though there are still some indicators that have to be improved. The expectation is in order to improve the skills of practical skills to maximum students.
\end{abstract}

Keyword: work based learning, practical skills

Pengembangan metode pembelajaran pada sekolah menengah kejuruan merupakan program pemerintah guna menghasilkan lulusan yang dapat siap kerja dengan kemampuan practical skills yang dimilikinya (Joice \& Wells, 2009). Practical skills itu sendiri merupakan kemampuan setiap individu tentang seberapa banyak ilmu pengetahuan dan keterampilan menggunakan teknologi yang dimilikinya. Semakin banyak ilmu pengetahuan dan keterampilan penggunaan teknologi yang dimiliki peserta didik SMK, maka semakin besar pula peluang peserta didik tersebut diterima bekerja di dunia industri atau berwira usaha.

Depdiknas (2003) metode pembelajaran work-based-learning merupakan strategi pembelajaran yang membuat peserta didik dapat menggunakan suatu konteks tempat kerja untuk mempelajari materi pembelajaran berbasis sekolah. Dalam suatu metode pembelajaran diperlukan evaluasi agar dapat mengetahui seberapa efektif penerapan motede tersebut. Arikunto (2004) 
CIPP terdiri dari sistem kerja yang dinamis, bersifat holistik, dapat melakukan perbaikan program selama evaluasi, dan lebih komprehensif dibanding dengan jenis evaluasi metode lainnya. Di SMK Turen merupakan salah satu sekolah kejuruan yang menerapkan metode pembelajaran work-based learning guna meningkatkan kemampuan practical skills peserta didiknya. Masalah yang dihadapi di SMK Turen adalah belum pernah diadakan evaluasi pembelajaran terhadap model pembelajaran work-based learning yang diterapkannya.

Berdasarkan masalah tersebut dipilihlah SMK Turen sebagai tempat penelitian. Tujuan penelitian tersebut yaitu untuk mengetahui peningkatan practical skills peserta didik yang telah melalui mata pelajaran pekerjaan dasar teknik mesin dengan model pembelajaran work-based learning. CIPP dipilih sebagai model evaluasi yang akan digunakan untuk mengetahui apakah penerapan metode pembelajaran work-based learning dapat meningkatkan kemampuan practical skills peserta didik. Dipilihnya CIPP sebagai model evaluasi dikarenakan sangat terperinci hasil evaluasi yang dihasilkan meliputi empat faktor, yaitu: (1) Contect merupakan komponen yang digunakan untuk mengetahuai dasar-dasar atau acuan-acuan diterapkannya pembelajaran pekerjaan dasar teknik mesin; (2) Input merupakan komponen yang digunakan untuk mengetahui seberapa besar kesiapan yang dimiliki untuk menjalankan pembelajaran pekerjaan dasar teknik mesin mulai dari sumber daya manusia, sarana dan prasarana yang dibutuhkan, dan juga sumber dana yang digunakan; (3) Process merupakan komponen yang digunakan untuk melihat, mencatat, dan mendokumentasikan berjalannya pembelajaran pekerjaan dasar teknik mesin; dan (4) Product merupakan komponen yang digunakan untuk melihat dampak atau hasil yang didapatkan dari penerapan suatu program tersebut.

\section{METODE}

Penelitian ini menggunakan pendekatan deskriptif kuantitatif. Penelitian ini dilakukan di SMK Turen jurusan teknik pemesinan. Populasi dan sampel pada penelitian ini adalah seluruh siswa kelas 10 teknik pemesinan sebanyak 180 peserta didik dan dilakukan penelitian terhadap 60 peserta didik sebagai sampel uji coba dan 120 peserta didik sebagai sampel penelitian. Penelitian ini menggunakan instrumen penelitian skala likert yaitu (SS: sangat setuju, S: setuju, TS: tidak setuju, STS: sangat tidak setuju) (Sugiono, 2008). Instrumen penelitian skala likert dipilih untuk mempermudah gambaran terkait hasil pada tiaptiap variabel. Berikut merupakan gambaran penilaian berdasarkan tiap variabel: (1). Variabel konteks terdiri dari indikator tujuan dan sasaran; (2). Variabel input terdiri dari indikator sumber daya, infrastruktur, dan kurikulum; (3). Variabel proses terdiri dari indikator konten, proses belajar mengajar, dan evaluasi kegiatan; (4). Variabel produk terdiri dari indikator keterampilan, nilai, sikap, dan hasil. Teknik pengumpulan data yang digunakan adalah angket dan wawancara. Pengumpulan data dari angket, dikelompokkan sesuai dengan bentuk instrumen yang digunakan, disajikan dalam bentuk tabel, dianalisis dan ditafsirkan kemudian. Teknis analisis data yang digunakan yaitu deskriptif dengan bantuan aplikasi SPSS 25.0.

Tabel 1. Kerangka kerja evaluasi CIPP yang diterapkan pada pembelajaran PDTM

\begin{tabular}{|c|c|c|c|c|}
\hline & Kontek & Input & Proses & Produk \\
\hline Tujuan & $\begin{array}{l}\text { *Untuk menilai } \\
\text { tujuan } \\
\text { pembelajaran } \\
\text { *Untuk menilai } \\
\text { sasaran program }\end{array}$ & $\begin{array}{l}\text { *Untuk menilai } \\
\text { sumber daya yang } \\
\text { tersedia } \\
\text { *Untuk menilai } \\
\text { infrastruktur } \\
\text { penunjang } \\
\text { program } \\
\text { *Untuk menilai } \\
\text { kelayakan } \\
\text { kurikulum }\end{array}$ & $\begin{array}{l}\text { *Untuk menilai } \\
\text { kesesuai konten } \\
\text { dengan RPP } \\
\text { *Untuk menilai } \\
\text { kegiatan proses } \\
\text { belajar mengajar } \\
\text { *Untuk menilai } \\
\text { evaluasi } \\
\text { pembelajaran yang } \\
\text { dilakukan }\end{array}$ & $\begin{array}{lr}\text { *Untuk } & \text { menilai } \\
\text { keterampilan } & \text { yang } \\
\text { dihasilkan } & \\
\text { *Untuk } & \text { mengetahui } \\
\text { nilai hasil pembelajaran } \\
\text { *Untuk } & \text { mengetahui } \\
\text { sikap } & \text { hasil } \\
\text { pembelajaran } & \\
\text { *Untuk } & \text { menilai } \\
\text { kesesuaian } & \text { hasil } \\
\text { pembelajaran. } & \\
\end{array}$ \\
\hline $\begin{array}{l}\text { Subjek } \\
\text { Penelitian }\end{array}$ & $\begin{array}{l}\text { Peserta didik dan } \\
\text { guru pengajar }\end{array}$ & $\begin{array}{l}\text { Peserta didik dan } \\
\text { guru pengajar }\end{array}$ & $\begin{array}{l}\text { Peserta didik dan } \\
\text { guru pengajar }\end{array}$ & $\begin{array}{l}\text { Peserta didik dan guru } \\
\text { pengajar }\end{array}$ \\
\hline Indikator & 2 indikator & 3 indikator & 3 indikator & 4 indikator \\
\hline
\end{tabular}




\section{HASIL}

Persiapan yang dilakukan oleh SMK Turen dalam penerapan pembelajaran PDTM untuk meningkatkan practical skills peserta didiknya dibagi menjadi empat variabel evaluasi mulai dari konteks, input, proses, dan produk yang dihasilkan. Seluruh data dalam penelitian ini dikumpulkan menggunakan angket terhadap seluruh sampel uji, kemudian di lakukan uji validitas dan reliabilitas sehingga siap untuk dianalisis.

Deskripsi mengenai variabel-variabel penelitian hasil analisis menggunakan evaluasi CIPP disajikan pada Tabel 1. Dalam Tabel tersebut dapat dilihat mengenai skor maksimum-minimum, modus, mean, standar deviasi, dan kategori tingkatan.

Tabel 2. Hasil Analisis Deskriptif Variabel-Variabel Penelitian

\begin{tabular}{llllll}
\hline Variabel & $\begin{array}{l}\text { Skor } \\
\text { Maksimum } \\
\text { Minimum }\end{array}$ & Modus & Mean & $\begin{array}{l}\text { Standar } \\
\text { Deviasi }\end{array}$ & $\begin{array}{l}\text { Kategori } \\
\text { Tingkatan }\end{array}$ \\
\hline Konteks & $2-4$ & 3 & 3,45 & 0,523 & $86,37 \%$ \\
Input & $1-4$ & 3 & 3,23 & 0,638 & $80,66 \%$ \\
Proses & $1-4$ & 3 & 3,12 & 0,655 & $77,93 \%$ \\
Produk & $1-4$ & 3 & 3,27 & 0,639 & $81,84 \%$ \\
\hline
\end{tabular}

Untuk kategori tingkatan diperoleh persentase tersebut berdasarkan pendapat ahli yang menjadi rujukan yaitu sebagai berikut: $0 \%-20 \%$ yaitu tergolong tingkatan buruk sekali, $21 \%-40 \%$ yaitu tergolong tingkatan buruk, $41 \%-60 \%$ yaitu tergolong tingkatan sedang, $61 \%$ - $80 \%$ yaitu tergolong tingkatan baik, dan $81 \%-100 \%$ yaitu tergolong tingkatan baik sekali. Hasil persentase tersebut diperoleh dengan cara pembagian jumlah skor yang terkumpul dibagi dengan jumlah skor maksimal kemudian dikali dengan seratus persen.

Tabel 3. Data Hasil Evaluasi Konteks

\begin{tabular}{lcccc}
\hline \multicolumn{1}{c}{ Pernyataan } & $(\mathrm{SS})$ & $(\mathrm{S})$ & $(\mathrm{TS})$ & $(\mathrm{STS})$ \\
& $\mathrm{N}(\%)$ & $\mathrm{N}(\%)$ & $\mathrm{N}(\%)$ & $\mathrm{N}(\%)$ \\
\hline memenuhi kebutuhan anda? & $48(39,3)$ & $64(52,5)$ & $10(8,2)$ & 0 \\
\hline sesuai untuk pengetahuan awal anda? & $57(46,7)$ & $60(49,2)$ & $5(4,1)$ & 0 \\
\hline sesuai dengan harapan anda? & $42(34,4)$ & $66(54,1)$ & $14(11,5)$ & 0 \\
\hline menambah ilmu pengetahuan anda? & $48(39,3)$ & $63(51,6)$ & $11(9,0)$ & 0 \\
\hline sudah tepat digunakan? & $51(41,8)$ & $70(57,4)$ & $1(0,8)$ & 0 \\
\hline meningkatkan kemampuan praktik anda? & $63(51,6)$ & $57(46,7)$ & $2(1,6)$ & 0 \\
\hline
\end{tabular}

Tabel 4. Data Hasil Evaluasi Input

\begin{tabular}{lcccc}
\multicolumn{1}{c}{ Pernyataan } & $(\mathrm{SS})$ & $(\mathrm{S})$ & $(\mathrm{TS})$ & $(\mathrm{STS})$ \\
& $\mathrm{N}(\%)$ & $\mathrm{N}(\%)$ & $\mathrm{N}(\%)$ & $\mathrm{N}(\%)$ \\
\hline apakah guru pengajar berkompeten? & $26(21,3)$ & $87(71,3)$ & $9(7,4)$ & 0 \\
\hline sudah terpenuhi keperluan pembelajaran? & $44(36,1)$ & $72(59,0)$ & $6(4,9)$ & 0 \\
\hline mata pelajaran PDTM ini diperlukan? & $67(54,9)$ & $53(43,4)$ & $2(1,6)$ & 0 \\
\hline alat-alat pelajaran PDTM membantu anda belajar? & $45(36,9)$ & $70(57,4)$ & $6(4,9)$ & $1(0,8)$ \\
\hline alat-alat pelajaran PDTM menarik perhatian anda? & $36(29,5)$ & $74(60,7)$ & $9(7,4)$ & $3(2,5)$ \\
\hline $\begin{array}{l}\text { mata pelajaran PDTM memiliki efek positif pada practical skill } \\
\text { anda? }\end{array}$ & $44(36,1)$ & $72(59,0)$ & $6(4,9)$ & 0 \\
\hline $\begin{array}{l}\text { alat-alat pelajaran PDTM membantu anda belajar? } \\
\text { mata pelajaran PDTM menarik perhatian anda? }\end{array}$ & $33(27,0)$ & $82(67,2)$ & $5(4,1)$ & $2(1,6)$ \\
\hline $\begin{array}{l}\text { mata pelajaran PDTM memiliki efek positif pada practical skill } \\
\text { anda? }\end{array}$ & $54(44,3)$ & $60(49,2)$ & $6(4,9)$ & $2(1,6)$ \\
\hline
\end{tabular}


Tabel 5. Data Hasil Evaluasi Proses

\begin{tabular}{lcccc}
\multicolumn{1}{c}{ Pernyataan } & $(\mathrm{SS})$ & $(\mathrm{S})$ & $(\mathrm{TS})$ & $(\mathrm{STS})$ \\
& $\mathrm{N}(\%)$ & $\mathrm{N}(\%)$ & $\mathrm{N}(\%)$ & $\mathrm{N}(\%)$ \\
\hline $\begin{array}{l}\text { pelatihan kerja dilakukan setiap topik baru? } \\
\text { pekerjaan rumah diberikan pada setiap topik baru? }\end{array}$ & $35(28,7)$ & $76(62,3)$ & $11(9,0)$ & 0 \\
\hline $\begin{array}{l}\text { setiap topik baru dilakukan ujian tes? } \\
\text { embelajaran dikerjakan secara berkelompok? }\end{array}$ & $27(22,1)$ & $62(50,8)$ & $25(20,5)$ & $8(6,6)$ \\
\hline $\begin{array}{l}\text { semua kemampuan kerja anda sudah dapat digunakan dalam } \\
\text { pembelajaran? }\end{array}$ & $32(34,4)$ & $69(56,6)$ & $13(10,7)$ & $4(3,3)$ \\
\hline $\begin{array}{l}\text { waktu yang diberikan untuk menyelesaiakan job sudah cukup? } \\
\text { dilakukan revisi dalam mata pelajaran? }\end{array}$ & $23(18,9)$ & $82(67,2)$ & $14(11,5)$ & $3(2,5)$ \\
\hline $\begin{array}{l}\text { perlu diadakannya evaluasi terhadap peningkatan practical } \\
\text { skills? }\end{array}$ & $22(18,0)$ & $90(73,8)$ & $7(5,7)$ & $3(2,5)$ \\
\hline $\begin{array}{l}\text { tidak perlu diadakannya evaluasi terhadap peningkatan } \\
\text { practical skills? }\end{array}$ & $34(27,9)$ & $79(64,8)$ & $6(4,9)$ & $3(2,5)$ \\
\hline
\end{tabular}

Tabel 6. Data Hasil Evaluasi Produk

\begin{tabular}{|c|c|c|c|c|}
\hline Pernyataan & $\begin{array}{c}(\mathrm{SS}) \\
\mathrm{N}(\%) \\
\end{array}$ & $\begin{array}{c}(\mathrm{S}) \\
\mathrm{N}(\%) \\
\end{array}$ & $\begin{array}{c}(\mathrm{TS}) \\
\mathrm{N}(\%) \\
\end{array}$ & $\begin{array}{c}\text { (STS) } \\
\mathrm{N}(\%) \\
\end{array}$ \\
\hline $\begin{array}{l}\text { mata pelajaran PDTM ini sudah dapat meningkatkan practical } \\
\text { skill (kepresisian)? }\end{array}$ & $40(32,8)$ & $76(62,3)$ & $5(4,1)$ & $1(0,8)$ \\
\hline $\begin{array}{l}\text { mata pelajaran PDTM ini sudah dapat meningkatkan practical } \\
\text { skill (kehalusan)? }\end{array}$ & $41(33,6)$ & $78(63,9)$ & $3(2,5)$ & 0 \\
\hline $\begin{array}{l}\text { mata pelajaran PDTM ini sudah dapat meningkatkan practical } \\
\text { skill (pemakaian alat)? }\end{array}$ & $42(34,3)$ & $74(60,7)$ & $4(3,3)$ & $2(1,6)$ \\
\hline $\begin{array}{l}\text { penilaian practical skill disekolah sudah dilakukan sesuai } \\
\text { dengan harapan anda? }\end{array}$ & $45(36,9)$ & $71(58,2)$ & $5(4,1)$ & $1(0,8)$ \\
\hline $\begin{array}{l}\text { penilaian practical skill dirumah sudah dilakukan sesuai dengan } \\
\text { harapan anda? }\end{array}$ & $28(23,0)$ & $74(60,7)$ & $15(12,3)$ & $5(4,1)$ \\
\hline hasil penilaian hanya melalui tugas disekolah dan rumah? & $28(23,0)$ & $58(47,5)$ & $25(20,5)$ & $11(9,0)$ \\
\hline mata pelajaran PDTM dapat memotivasi dalam belajar anda? & $41(33,6)$ & $75(61,5)$ & $5(4,1)$ & $1(0,8)$ \\
\hline $\begin{array}{l}\text { mata pelajaran PDTM membentuk dasar practical skill yang } \\
\text { dibutuhkan? }\end{array}$ & $57(46,7)$ & $60(49,2)$ & $4(3,3)$ & $1(0,8)$ \\
\hline $\begin{array}{l}\text { mata pelajaran PDTM dapat membentuk karakter dalam } \\
\text { practical skill? }\end{array}$ & $56(45,9)$ & $62(50,8)$ & $3(2,5)$ & $1(0,8)$ \\
\hline $\begin{array}{l}\text { mata pelajaran PDTM sudah membantu anda memperoleh } \\
\text { kemampuan practical skill yang dibutuhkan dalam keseharian? }\end{array}$ & $40(32,8)$ & $76(62,3)$ & $5(4,1)$ & $1(0,8)$ \\
\hline $\begin{array}{l}\text { mata pelajaran PDTM sudah membantu anda memperoleh } \\
\text { kemampuan practical skill yang dibutuhkan dalam proses } \\
\text { studi? }\end{array}$ & $46(37,7)$ & $73(59,8)$ & $2(1,6)$ & $1(0,8)$ \\
\hline $\begin{array}{l}\text { mata pelajaran PDTM sudah membantu anda memperoleh } \\
\text { kemampuan practical skill yang dibutuhkan nantinya dalam } \\
\text { bekerja? }\end{array}$ & $65(53,3)$ & $55(45,1)$ & $2(1,6)$ & 0 \\
\hline
\end{tabular}

\section{Konteks}

Hasil analisis mengetahui tentang seberapa baiknya tingkatan konteks yang dilakukan pada pembelajaran PDTM di SMK Turen, sehingga dilakukan peninjauan terhadap; 1. Sasaran, 2. Tujuan. Pada Tabel 2, dapat dilihat bahwa tingkatan variabel konteks dengan mean 3,45 dan standar deviasi 0,523 adalah termasuk ke dalam tingkatan yang baik sekali dengan persentase sebesar $86,37 \%$. 
Sasaran

Wirawan (2011) evaluasi konteks mengidentifikasi sasaran dan menilai kebutuhan-kebutuhan yang mendasari disusunnya suatu program. Sasaran penelitian merupakan peserta didik baru SMK Turen yaitu kelas X jurusan teknik mesin. Menurut hasil penyataan dari seluruh subjek uji menyatakan bahwa pembelajaran PDTM ini sudah termasuk kedalam kategori sangat baik. Pernyataan yang mayoritas diberikan yaitu sangat cocoknya jika mata pelajaran PDTM diberikan pada kelas X jurusan teknik mesin, memberikan tambahan ilmu mengenai teknik mesin yang belum pernah didapatkan dijenjang pendidikan sebelumnya, dan meningkatkan kemampuan dasar praktik sebelum melakukan praktik tingkat lanjut.

\section{Tujuan}

Arikunto (2004) melakukan penelitian konteks dengan menggunakan indikator tujuan penelitian. Selaras dengan penelitian tersebut menjadikan acuan dipilihnya indikator tujuan sebagai salah satu indikator dalam variabel konteks. Tujuan dari adanya pembelajaran PDTM untuk kelas X ini adalah peserta didik diharapkan: (1). Memiliki kemampuan perbengkelan yang sama satu dengan lainnya; (2). Mampu menggunakan perkakas perbengkelan; (3). Mampu menerapkan pengetahuan K3 dalam melakukan pekerjaan perbengkelan; (4). Mampu melakukan pekerjaan dengan tingkat kepresisian yang tinggi; dan (5). Mampu menerapkan ketelitian tinggi tiap pekerjaan. Menurut hasil penyataan dari seluruh subjek uji menyatakan bahwa pembelajaran PDTM ini sudah termasuk kedalam kategori sangat baik. Kategori tersebut diperoleh dari hasil penyataan yang menyatakan bahwa pembelajaran PDTM ini sudah sangat membantu proses pembelajaran di teknik mesin terutama dalam hal praktik dan sudah sangat memenuhi harapan untuk pengetahuan dasar tentang segala hal mengenai teknik mesin.

Input

Hasil analisis mengetahui tentang seberapa baiknya tingkatan input yang dilakukan pada pembelajaran PDTM di SMK Turen, sehingga dilakukan peninjauan terhadap; 1. Sumber daya, 2. Infrastruktur, 3. Kurikulum. Pada Tabel 2, dapat dilihat bahwa tingkatan variabel input dengan mean 3,23 dan standar deviasi 0,638 adalah termasuk ke dalam tingkatan yang baik dengan persentase sebesar $80,66 \%$.

\section{Sumber Daya Manusia}

WBL Guide (2002) evaluasi input meliputi sumber daya manusia, sarana dan prasarana pendukung, dana anggaran, dan aturan yang diperlukan. Berdasarkan hasil analisis dapat disimpulkan bahwa sumber daya manusianya baik itu dari pimpinan, staf, guru pengajar, dan peserta didik sudah sangat baik. Hasil tersebut diperoleh menurut sumber penelitian berdasarkan dua sudut pandang yaitu guru pengajar dan peserta didik sehingga dapat disimpulkan bahwa sumber daya manusia yang berada di STM Turen sudah sangat baik untuk melakukan proses pembelajaran PDTM. Berdasarkan sudut pandang pengajar kemampuan praktikum yang dilihat dari peserta didik sudah sangat baik dengan cara minimnya peserta didik untuk meninggalkan kelas baik itu tidak masuk atau keluar kelas praktikum, sehingga ilmu yang diberikan bisa disampaikan tanpa ada yang tertinggal. Untuk sudut pandang peserta didik yang dinyatakan dalam angket menghasilkan kesimpulan bahwa guru pengajar mata pelajaran PDTM sudah berkompeten dibidangnya dan juga segala sesuatu yang dibutuhkan dalam proses pembelajaran PDTM sudah terpenuhinya sehingga peserta didik terlalu mengalami kesulitan dalam proses pembelajarannya.

\section{Infrastruktur}

Nurhadi (2012) kondisi peralatan dan ruangan yang ada mampu mendukung dalam mengidentifikasi suatu kegiatan. Pernyataan tersebut dijadikan acuan masuknya indikator infrastruktur dalam variabel ini. Hasil analisis indikator ini sebenarnya termasuk kategori sangat baik, tetapi nyatanya dilapangan masih belum sesuainya infrastruktur dalam proses pembelajaran PDTM dengan standar industri yang dilakukan pengamatan langsung. Hal ini disebabkan penggunaan alokasi anggaran dana yang harus dibagi merata di tiap jurusan yang ada di SMK Turen sehingga tidak untuk menyetarakan standar industri cukup sulit meskipun seluruh alat-alat yang ada sudah cukup lengkap. Hasil tersebut sangat berbeda dengan hasil yang diperoleh diperoleh dari hasil angket yang menyatakan bahwa peserta didik sudah puas terhadap peralatan yang digunakan dalam proses pembelajar dikarenakan sudah dapat membantu, mempermudah, dan menarik peserta didik supaya senang dengan proses pembelajaran PDTM tersebut.

\section{Kurikulum}

Zhang (2011) input meliputi mengidentifikasi, menilai strategi dan desain prosedural pembelajaran. Pernyataan dipertegas oleh WBL Guide (2002) menjelaskan evaluasi input meliputi sumber daya manusia, sarana dan prasarana pendukung, dana anggaran, dan aturan yang diperlukan. Kurikulum dalam penelitian ini bermakna aturan yang dibuat dalam pembelajaran PDTM, sehing disini pengajar dituntut dapat melaksanakan proses belajar mengajar sesuai kurikulum yang sudah ditetapkan oleh pihak sekolah. Hasil penelitian ini sudah termasuk kedalam kategori baik dikarenakan SMK Turen sudah 
menerapkan aturan pembelajaran berbasis teaching factory pada setiap pembelajaran produktif meliputi PDTM. Teaching factory merupakan pembelajaran berbasis hasil berupa produk jadi dan bisnis merupakan usaha jual dari hasil. Dalam kategori baik tersebut, masih terdapat kekurangan dalam segi teknis pembuatan prangkat pembelajaran sebagai aturan maupun pedoman pengajar dalam melakukan proses belajar mengajar. Perangkat pembelajaran yang seharusnya sudah terbentuk sebelum proses kegiatan belajar pembelajaran ini ternyata masih belum dapat terselesaikan hingga dimulainya proses kegiatan belajar mengajar. Sehingga membuat pengajar merasa kurangnya kesiapan untuk melakukan pengajaran kepada peserta didik.

\section{Proses}

Hasil analisis mengetahui tentang seberapa baiknya tingkatan proses yang dilakukan pada pembelajaran PDTM di SMK Turen, sehingga dilakukan peninjauan terhadap; 1. konten, 2. proses belajar mengajar 3. Evaluasi kegiatan. Pada Tabel 2, dapat dilihat bahwa tingkatan variabel proses dengan mean 3,12 dan standar deviasi 0,655 adalah termasuk ke dalam tingkatan yang baik dengan persentase sebesar $77,93 \%$.

\section{Konten}

Siswanto (2010) melakukan proses pembelajaran perlu adanya rancangan program pembelajaran berupa silabus dan desain pembelajaran serta rancangan sistem asesmennya mengacu pada standar kompetensi lulusan dari satuan pendidikan yang bersangkutan. Menurut pendapat ahli tersebut konten disini diartikan sebagai rancangan program pembelajaran yang disesuaikan dengan KI dan KD pada industri. KI dan KD pada rancangan program pembelajaran harus menyesuaikan KI dan KD pada sektor industri dikarenakan kurikulum berbasis teaching factory yang diterapkan di SMK Turen mengharapkan ketika peserta didik lulus nantinya memiliki keterampilan practical skills sesuai dengan standar industri. Hasil penelitian tergolong dalam kriteria baik. Hasil tersebut tidak terlepas dari terlaksananya materi KI dan KD yang sudah tersusun sebelumnya. Pernyataan yang diperolehpun cukup baik dikarenakan peserta didik berharap bahwa setiap KI dan KD yang diajarkan dapat diberikan pelatian practical skills, pemberian tugas rumah, dan dilakukannya tes terstruktur.

\section{Proses Belajar Mengajar}

Wirawan (2011) proses salah satunya berupaya melaksanakan aktivitas pembelajaran. Zhang (2011) proses bertujuan untuk memantau proses proyek dan identifikasi kebutuhan untuk penyesuaian proyek. Aktivitas pembelajaran yang diungkapkan oleh ahli tersebut diartikan sebagai berlangsungnya proses belajar mengajar yang dilakukan pengajar dan peserta didik dalam pembelajaran PDTM. Dalam hasil peneltian, indikator tersebut termasuk kedalam kategori tingkatan baik. Dari hasil yang dicapai tersebut sebenarnya sudah baik melainkan masih perlunya peningkatan. Kategori tersebut tidak mencapai sangat baik dikarenakan terdapat kendala-kendala yang terjadi dalam proses belajar mengajar terutama pada peserta didik. Peserta didik tidak mampu mempertahankan konsentrasi belajarnya pada saat berlangsungnya proses pembelajaran. Tidak mampunya peserta didik menjaga konsentrasinya tidak terlepas pula dari peran pengajar juga. Disini peran guru pengajar juga sangat penting yang harus dilakukan. Kurangnya rancangan proses pembelajaran yang matang dan motode pembelajaran membuat sulitnya mengembalikan kensentrasi peserta didik yang sudah terpecah pada saat proses pembelajaran berlangsung.

\section{Evaluasi Kegiatan}

Wirawan (2011) perlunya penilaian aktivitas dan menginterprestasikan manfaat. Pada indikator ini dilakuan kegiatan evaluasi karena dengan adanya evaluasi dapat diketahui berbagai macam kelemahan yang kemudihan dapat diketahui jalan penyelesaiannya. Nilai ini tergolong nilai rendah di antara variabel lain meskipun masih termasuk standar ketuntasan karena beberapa alasan mulai dari kurang lengkapnya sarana dan prasarana, perbandingan rasio peserta didik yang sangan banyak sehingga kurangnya pengawasan dari guru pengajar, masih kurangnya antusias peserta didik dalam proses pembelajaran karena metode yang digunakan guru pengajar cenderung monoton dengan cara ceramah. Tetapi secara garis besar berdasarkan hasil pernyataan pada angket dapat disimpulkan bahwa masih perlunya dilakukan evaluasi yang mendalam dan revisi-revisi dalam pembelajaran PDTM ini guna meningkatkan kemampuan practical skills peserta didik. Kesimpulan tersebut didukung juga oleh pengamatan yang dilakukan di lapangan dengan cara visual dan dokumentasi.

\section{Produk}

Hasil analisis mengetahui tentang seberapa baiknya tingkatan produk yang dilakukan pada pembelajaran PDTM di SMK Turen, sehingga dilakukan peninjauan terhadap; 1. Keterampilan, 2. Nilai, 3. Sikap, 4. Hasil. Pada Tabel 2, dapat dilihat 
bahwa tingkatan variabel produk dengan mean 3,27 dan standar deviasi 0,639 adalah termasuk ke dalam tingkatan yang baik dengan persentase sebesar $81,84 \%$.

\section{Keterampilan}

Arikunto (2004) evaluasi produk atau hasil diarahkan pada hal-hal yang menunjukkan perubahan. Perubahan dalam pendapat diatas diartikan sebagai peningkatan kemampuan practical skills. Dalam hasil penelitian ini dapat dilihat termasuk tingkatan sangat baik. Diperolehnya tingkatan tersebut berdasarkan hasil pernyataan pada angket yang disebar. Pernyataan tersebut berisi bahwa subjek uji mendapatkan peningkatan practical skills pada indikator kepresisian, kehalusan, dan penggunaan alat-alat.

\section{Penilaian}

Smith (2002) bagian integral dalam proses pembelajaran yang dilakukan sebagai proses pengumpulan dan pemanfaatan informasi yang menyeluruh tentang hasil belajar yang diperoleh siswa untuk menetapkan tingkat pencapaian dan penguasaan kompetensi seperti yang ditentukan dalam kurikulum dan sebagai umpan balik untuk perbaikan proses pembelajaran. Dalam hal ini persentase yang dihasilan paling kecil diantara indikator lainnya meskipun masih tergolong cukup baik. Berdasarkan hasil penarikan angket data tersebut menunjukan bahwa peserta didik tidak memiliki kepuasan dengan cara penilaian yang dilakukan dalam hal praktik disekolah ataupun di rumah lewat bantan orang tua. Hal itu terjadi karena peserta didik merasa bahwa tidak dapat mengeluarkan potensi belajar yang maksimal disekolah dikarenakan kurangnya serana dan prasarana yang menunjang peserta didik dapat mengeluarkan secara maksimal potensi belajarnya.

\section{Sikap}

Stufflebeam (2015) evaluasi hasil pembelajaran merupakan salah satu bagian dalam proses pendidikan dan pelatihan karakter. Pelatihan karakter disini diartikan sebagai sikap prilaku yang juga dapat mempengaruhi kemampuan practical skills peserta didik yang menempuh pembelajaran PDTM. Dalam hasil ini termasuk dalam kategori sangat baik. Kategori tesebut dapat tercapai dikarenakan peserta didik merasa bahwa pelajaran PDTM ini dapat memotivasi semangat bekerja, memberikan dampak positif terhadap kemampuan bekerja tiap-tiap individu. Harapannya kelak ketika menempuh mata pelajaran praktikum di kelas XI dan XII sudah dengan mudah melakukannya tanpa banyak mengalami berbagai macam kendala dalam hal penggunaan alat dan juga diharapkan mampu terbiasa menerapkan K3 pada tiap pekerjaan yang dilakukannya.

Hasil

Sukmadinata (2005) kegiatan yang ditujukan pada hasil pelaksanaan program pembelajaran tersebut. Hasil analisa yang diperoleh indikator ini termasuk kedalam kategori sangat baik. Kategori tersebut diperoleh tidak terlepas dari pernyataan yang terdapat pada angket yang disebar yang menyatakan bahwa pelajaran PDTM ini dapat meningkatkan kemampuan practical skills peserta didik untuk melakukan pekerjaan rumah, praktikum di sekolah dan juga bekerja ketika peserta didik lulus. Maka dari itu perlu adanya proses pembelajaran mengenai PDTM untuk peserta didik baru yang masuk sebagai upaya penyerataan kemampuan dan pembekalan awal terkait praktik dan practical skills yang belum pernah didapatkan pada jenjang pendidikan sebelumnya.

\section{PENUTUP}

Penerapan pembelajaran PDTM dilihat dari variabel konteks yang bertujuan untuk peningkatan kemampuan practical skills peserta didik sudah sangat baik. Kategoti tersebut diperoleh dari analisis pernyataan angket yang disebar dan pengamatan juga dilakukan pengamatan langsung untuk melihat apakah memang sasaran dan tujuan pembelajaran yang tergolong indikator pada variabel konteks ini telah terpenuhi hingga diperolehnya kategori sangat baik. Analisis pernyataan pada indikator dan pengamatan yang dilakukan mendapatkan hasil yang dianggap sesuai dengan kategori yang diperoleh bahwa sasaran dan tujuan yang diingkan sudah sesuai dan berjalan sangat baik.

Penerapan pembelajaran PDTM dilihat dari variabel input yang bertujuan untuk peningkatan kemampuan practical skills peserta didik sudah baik. Kategoti tersebut diperoleh dari analisis pernyataan angket yang disebar dan pengamatan juga dilakukan pengamatan langsung untuk melihat apakah memang sumber daya manusia, infrastruktur, dan kurikulum pembelajaran telah terpenuhi hingga diperolehnya kategori baik. Pengamatan yang dilakukan mendapatkan hasil yang dianggap sesuai dengan kategori yang diperoleh bahwa sumber daya manusia, infrastruktur, dan kurikulum yang diinginkan sudah sesuai berdasarkan analisis pernyataan hasil angket. Dalam kategori baik tersebut masih diperlukannya beberapa perbaikan guna untuk meningkatkan kemampuan practical skills peserta didik secara maksimal dengan cara penambahan jumlah alat sehingga memperkecil perbandingan alat dan pengguna, lebih mempersiapkan lagi segala sesuai terkait pemenuhan prangkat pembelajaran jauh-jauh hari sehingga sebelum dimulainya proses belajar mengajar sudah dapat terselesaikan. 
Penerapan pembelajaran PDTM dilihat dari variabel proses yang bertujuan untuk peningkatan kemampuan practical skills peserta didik sudah cukup baik. Kategoti tersebut diperoleh dari analisis pernyataan angket yang disebar dan pengamatan juga dilakukan pengamatan langsung untuk melihat apakah memang konten, proses belajar mengajar, dan evaluasi pembelajaran dilakukan dengan kurang maksimal hingga diperolehnya kategori cukup baik yang merupakan hasil terendah diantara variabel lainnya. Pengamatan yang dilakukan mendapatkan hasil yang dianggap sesuai dengan kategori yang diperoleh bahwa konten, proses belajar mengajar, dan evaluasi pembelajaran belum maksimal diterapkan pada pembelajaran PDTM di SMK Turen. Rendahnya hasil analisi variabel proses dikarenakan perlu dilakukan pembaharuan KI dan KD sesuai standar industri, kurangnya rancangan proses pembelajaran yang matang dan motode pembelajaran yang disiapkan pengajar membuat sulitnya mengembalikan kensentrasi peserta didik yang sudah terpecah pada saat proses pembelajaran berlangsung, masih perlunya dilakukan evaluasi yang mendalam dan terstruktur mengenai pembelajaran PDTM ini guna meningkatkan kemampuan practical skills peserta didik.

Penerapan pembelajaran PDTM dilihat dari variabel produk yang bertujuan untuk peningkatan kemampuan practical skills peserta didik sudah baik. Kategoti tersebut diperoleh dari analisis pernyataan angket yang disebar dan pengamatan juga dilakukan pengamatan langsung untuk melihat apakah memang keterampilan, penilaian, sikap, dan hasil telah dilakukan dengan baik hingga diperolehnya kategori baik. Pengamatan yang dilakukan mendapatkan hasil yang memang sesuai dengan kategori yang diperoleh dikarenakan peserta didik sudah merasa puas sehingga dapat meningkatkan kemampuan practical skills sesuai dengan tujuan pembelajaran PDTM ini.

\section{DAFTAR RUJUKAN}

Arikunto, S. 2004. Dasar-Dasar Evaluasi Pendidikan. Jakarta: Bumi Aksara

Joice and Well. 2009. Models of Teaching (Model Model Pengajaran). Yogyakarta:Pustaka Pelajar.

Nurhadi, Didik. 2012. Efektifitas Model Evaluasi Berbasis Kompetensi Matakuliah Praktikum Kerja Bangku Di Jurusan Teknik Mesin Fakultas Teknik Universitas Negeri Malang. Jurnal Teknik Mesin. 20(1), Hal 1-14

Smith, E. (2002). Theory and practice : the contribution of off-the-job training to the development of apprenticeship and trainee. Journal of Vocational and Education Training, 54(3), 431-456

Stufflebeam, D. L. 2015. CIPP Evaluation Model Checklist: A Tool for Applying the CIPP Model to Assess Projects and Programs. (Online), (https://wmich.edu/evaluation/checklists), diakses 20 Maret 2019.

Sugiyono. 2008. Metode Penelitian Kuantitatif, Kualitatif, dan R\&D. Bandung: Alfabeta

Sukmadinata, N.S. 2011. Metode Penelitian Pendidikan. Bandung: Remaja Rosadakarya

Wirawan. 2011. Evaluasi Teori Model Standar Aplikasi dan Profesi, Contoh Aplikasi Evaluasi Program: Pengembangan Sumber Daya Manusia, Program Nasional Pemberdayaan Masyarakat (PNPM) Mandiri Pedesaan, Kurikulum, Perpustakaan, dan Buku Tes. Jakarta: Raja Grafindo Persada

Work-based learning guide 2002. Diakses pada tanggal 2 Februari 2019

Zhang, G., Zeller, N., Griffith, R., Metcalf, D., Williams, J., Shea, C., \& Misulis, K. 2011. Using the Context, Input, Process, and Product Evaluation Model (CIPP) as a Comprehensive Framework to Guide the Planning, Implementation, and Assessment of Service-learning Programs. Journal of Higher Education Outreach and Engagement. Vol 15(4). Halaman $57-84$ 